Indonesian Journal of Medicine (2016), 1(1): 26-33

https://doi.org/10.26911/theijmed.2016.01.01.04

\title{
miR-21 Expression in Grade I, II, and III Breast Cancer
}

\author{
Juwita1)2), Henny E.S. Ompusunggu(1)3),Donny Nauphar4), Sumondang \\ M. Pardede5), Hadyanto Lim ${ }^{6)}$ ), Yahwardiah Siregar1)8)
}
${ }^{1)}$ MastersProgram in Biomedical Sciences, Faculty of Medicine, North SumatraUniversity, Medan 2) Department of Biochemistry, Faculty of Medicine, Syiah Kuala University, Banda Aceh 3) Department of Cellular and Molecular Biology, Faculty of Medicine, HKBP Nommensen University, Medan
4) Department of Biochemistry, Faculty of Medicine, Swadaya Gunung Jati University, Cirebon 5)Department of Anatomical Pathology Dr H. Adam Malik Hospital, Medan
6) Department of Pharmacology, Faculty of Medicine, Methodist Indonesia University, Medan
7) Department Biomolecular, Faculty of Medicine, Methodist Indonesia University, Medan 8)Department of Biochemistry, Faculty of Medicine, North Sumatra University, Medan

\begin{abstract}
Background: Breast cancer is the second largest cancer in the world.The gold standard for breast cancer diagnosis and prognosis is grade assessment (mitotic, nuclear pleiomorphism, tubular formation), based on breast tissue histopathology. However, this assessment has limitation in that it is subjective and semi quantitative. A genetic biomarker known as microRNA (miRNA) may regulate human gene expression by targetting mRNA. One of the miRNA, i.e. miR-21, is able to suppress tumor suppressor mRNA, resulting in increased cellular proliferation andneoplastic transformation, and decreased apoptosis. This study aimed to investigate the expression of miR-21in breast cancer with histopathologic grade I, II, and III.

Subjects and Method: This was a descriptive study with cross-sectional design involving paraffin block (FFPE) samples of ductal-type breast cancer tissue. Sixty four samples were obtained from the department of Anatomical Pathology, Haji Adam Malik Hospital, Medan. Patients history were obtained through medical records followed by sample processing (Total RNA Isolation, cDNA Synthesis, and Examination of miR-21 Expression using Real-Time qPCR). MiR-21 expression from every hystopathologic grade was obtained using Fold Change Calculation.

Results: Breast cancer occurred more frequently in age group of 30-49 years old. Based on the histopathologic grade, most breast cancer was found in grade II. Analysis of miR-21 expression showed that miR-21 expression was higher in grade III compared to other grade.

Conclusion: Breast cancer occured more frequently in the productive age group.Most breast cancer were found in grade II. Increased miR-21 expression in grade III may suggest that miR-21 is an oncomiR, which plays an important role in the development of malignant breast cancer.
\end{abstract}

Keywords: breast cancer, histopathology grade, miRNA, miR-21.

\section{Correspondance :}

Juwita. Masters Program in Biomedical Sciences, Faculty of Medicine, North SumateraUniversity, Medan. Mobile: 08125262339.

\section{BACKGROUND}

Breast cancer is the second most common cancer in the world (Ferlay et al., 2010; Kementerian Kesehatan Indonesia, 2013). According to the data from Haji Adam Malik Central Hospital, Medan, Indonesia, there were 200 new patients diagnosed with breast cancer during 2012. Histopathology examination of breast tissue is a Gold Standard for the diagnosis enforcement, and also for prognosis prediction through histopathology grade. Histopathology is an assessment toward the degree of cancer differentiation (cell mitosis, pleomorphism of cell nucleus, and tubulus formation), 
which is related to patients' prognosis prediction (Tavassoli and Deville, 2003; Malhotra et al., 2010). The assessment method is already commonly used (Rakha et al, 2010), however it has limitation since it is subjective and semi quantitative. Therefore other more objective biomarkers are needed to complement prognosis. A relatively potential biomarker of breast cancer which is also frequently investigated currently is microRNA.

MicroRNA (MiRNA) is a non-coding endogen RNA with 18-22 nucleotides in length, and also plays an important role in the regulation of gene expression. MiRNA works by degrading or impeding the translation of mRNA target; so that miRNA is able to influence protein expression (Calin and Croce, 2006; Cho, 2007), including protein which acts in the development of breast cancer. MicroRNA-21 (miR-21) is a micro RNA which experience increasing expression in breast cancer, by suppressing or impeding protein translation of tumor suppressor (Ioro et al, 2005). It results in the uncontrolled cell proliferation (can be assessed through grading component that is cell mitosis calculation). The excessive expression of miR-21 in breast cancer patients is suspected to be related with poor prognosis (Lee et al., 2011).

In Indonesia study on microRNA and its association with cancer is still very few, therefore this study aims to investigate the expression of miR-21 toward histopathology of patients' breast cancer tissue, especially in the city of Medan, Indonesia.

\section{SUBJECTS AND METHOD}

Research license has been obtained fro the Committee of Research Ethics of Faculty of Medicine, University of North Sumatra Medan Indonesia. The research design was cross sectional. The type was descriptive. The subject used was paraffin block (FFPE) of invasive ductal breast cancer tissue, with 64 subjects obtained from Pathology Anatomy Department of Haji Adam Malik Hospital Medan. Subject determination was conducted in purposive sampling, helped by Pathological Anatomist. The studied variable was the expression of miR-21 (independent) and the histopathology grade of breast cancer tissue (dependent). Data of research subject sampling was conducted in Haji Adam Malik Hospital Medan. The grade assessment was obtained from medical records data of breast cancer patients. miR-21 examination was conducted in Molecular Biology Laboratory of Faculty of Medicine UGM, through phases of RNA isolation from FFPE subject, examination on RNA concentration, cDNA synthesis, and analysis on miR-21 expression by using Real Time qPCR. Using Fold Change formulation, miR-21 was obtained in every grade of histopathology, subsequently, normality test and descriptive analysis were conducted.

\section{Total RNA Isolation of Paraffin Block (FFPE)}

Paraffin block was sliced by using microtome with $7 \mu \mathrm{m}$ of thickness, afterwards it was put into $1.5 \mathrm{ml}$ centrifuge tube. The Total RNA isolation process was conducted based on the manual of TiangenRNAprep Pure FFPE kit. Transfer $1 \mathrm{ml}$ of Xylene into the tube, vortexed and centrifuged at 12.000 rpm, afterward, supernatant was aspirated and disposed. Insert $1 \mathrm{ml}$ of ethanol, using similar phase as Xylene. Dry the pellet of ethanol. Insert buffer and proteinase $\mathrm{K}$ into the tube and vortexed. The tube was incubated in temperature $55^{\circ} \mathrm{C}$ and $80^{\circ} \mathrm{C}$. The tube was centrifuged and supernatant was transferred into new tube. Buffer was put inside new tube, and vortexed. Ethanol was added into the tube, and vortexed. The 
Indonesian Journal of Medicine (2016), 1(1): 26-33

https://doi.org/10.26911/theijmed.2016.01.01.04

mixture was transferred into Spin Column $\mathrm{CR}_{3}$, and centrifuged, afterward the liquid inside the tube was disposed. DNAse I solution was prepared, and put inside Spin Column CR3, then incubated for 15 minutes. Buffer RW1 was put inside Spin Column $\mathrm{CR}_{3}$, centrifuged, and disposed the liquid inside the tube. Insert buffer RW into Spin Column $\mathrm{CR}_{3}$, incubated for 2 minutes, centrifuged and disposed the liquid inside the tube. Collection tube was centrifuged for 2 minutes, and disposed the liquid inside the tube. Spin Column CR3 membrane was dried up. Spin Column $\mathrm{CR}_{3}$ was put in a new centrifuge tube, put $\mathrm{RNAse}-\mathrm{free}_{2} \mathrm{O}$ into membrane. The tube was closed, incubated and centrifuged until total RNS was obtained. The centrifuge tube with RNA Total inside and the tube were closed, and put inside refrigerator. Subsequently, total RNS concentration was examined by using NanoDrop Spectrophotometer.

\section{CDNA Syntesis of Total RNA}

The materials used were RNA sample, Reaction Buffer, Nuclease-Free Water, Spike in (UniSp6, as internal control), and Mixed Enzyme. The steps were conducted based on the manual cDNA synthesis kit from miRCURY LNA ${ }^{\mathrm{TM}}$ Universal RT microRNA PCR (Exiqon). RNA sample was slowly defrosted in room temperature, vortexed, and spun-down. Removed 5x Reaction Buffer, Nuclease-free water and Spike in (UniSp6) from refrigerator, defrosted in room temperature, vortexed and spun-down. Removed Mix Enzyme from refrigerator to be homogenized, to make Master Mix, after ward it was vortexed and spun-down. Master Mix was distributed to every PCR tube, then RNA sample was inserted into PCR tube, and spun-down. PCR tube subsequently was put inside RTPCR instrument, operate it according to its program. cDNS result was finally stored within refrigerator.

\section{Analysis miR-21 with Qrt-PCR}

The materials used were cDNA, SYBR Green Master Mix, primary miR-21 (has-miR-21), and primary UniSp6. The steps were conducted based on the manual kit from miRCURY LNA ${ }^{\mathrm{TM}}$ Universal RT microRNA PCR (Exiqon). cDNA was defrosted slowly in room temperature, vortexed, and spundown. cDNA was diluted in advance inside $1.5 \mathrm{ml}$ centrifuge tube, vontexed, and then spun-down. Removed SYBR Green Master Mix, Primary set miR-21 and Primary Spike in (UniSp6) from refrigerator to be homogenized by being thawed and vortexed to make Master Mix for has-miR-21 and Spike in control. The Master Mix was put into every qPCR tube, and then added with cDNA sample. Every tube was labeled and put into qRT-PCR machine, set the program into Real Time qPCR, and operate it according to its program.

\section{Statistical Analysis}

The data obtained is in a form of miR-21 expression (based on Fold Change formula from the obtained value of $\mathrm{Cq}$ miR-21 and UniSp 6 by using qRT-PCR), and followed by conducting normality test, KolmogorovSmirnov and descriptive analysis.

\section{RESULTS}

A descriptive analysis research had been conducted on the description of miR-21 expression toward histopathology grade of breast cancer, by using 64 subjects of paraffin block (FFPE) of invasive ductal type breast cancer tissue. Data analysis was conducted as follow:

\section{A. Characteristics of Research Subjects}

Table 1 presents the characteristics of research subjects obtained based on the age. It can be observed from Table 1 that the 
research subjects are mostly come from age group 30-49 year old which is 36 subjects
(56.30\%), compared to age group of $50-78$ year old.

Table 1. Distribution of research subjects based on age group

\begin{tabular}{cccccccccc}
\hline \multirow{2}{*}{$\begin{array}{c}\text { Age Groups } \\
\text { (Year) }\end{array}$} & \multicolumn{4}{c}{ Grade I } & \multicolumn{4}{c}{ Grade II } & \multicolumn{2}{c}{ Grade III } & \multicolumn{3}{c}{ Total } \\
\cline { 2 - 7 } & $\mathrm{n}$ & $\%$ & $\mathrm{n}$ & $\%$ & $\mathrm{n}$ & $\%$ & $\mathrm{n}$ & $\%$ \\
\hline $30-49$ & 6 & 40.00 & 28 & 73.70 & 2 & 18.20 & 36 & 56.30 \\
$50-78$ & 9 & 60.00 & 10 & 26.30 & 9 & 81.80 & 28 & 43.80 \\
Total & 15 & 100 & 38 & 100 & 11 & 100 & 64 & 100 \\
\hline
\end{tabular}

\section{B. Proportion of Histopathology Grade of Research Subjects}

According to the entire research subject, proportion of each histopathology grade of breast cancer was obtained as it is seen in the following picture 1 :

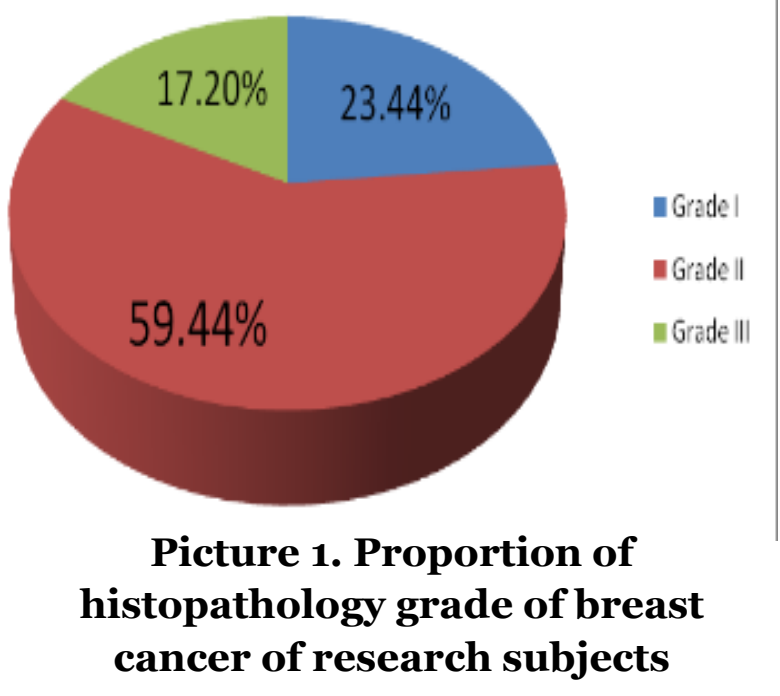

From Picture 1, it can be observed that the biggest proportion comes from grade ii which is 38 subjects (59.4\%), meanwhile the smallest proportion is grade III which 11 subjects (17.2\%).

C. Measuring miR-21 Expression in Breast Cancer Tissue of Research Subjects

miR-21 expression was measured by using qRT-PCR instrument, it was conducted to the entire research subjects. Based on the value of Cq miR-21 and UniSp6 from qRtPCR, the value was put into Fold Change Formula $\left(2^{-\Delta \mathrm{Cq})}\right.$ and obtained miR-21 expression data. Data normality test and descriptive test were conducted toward the data as it is presented in Table 2.

From Table 2 it can be found out that miR-21 expression data is distributed normally. The average of miR-21 expression was obtained from the result of descriptive test, and miR-21 expression in grade III is the highest that is $-0.49 \pm 1.28$. Whereas, the average of miR-21 expression on grade II is the lowest that is $-0.86 \pm 1.09$. The average of miR-21 expression in grade $\mathrm{I}$ is as much as $-0.66 \pm 1.45$.

Table 2. MiR-21 expression toward histopathology grade of breast cancer

\begin{tabular}{lcccccc}
\hline \multirow{2}{*}{ Diagnose } & \multicolumn{9}{c}{ miR-21 } & \multirow{2}{*}{ p } \\
\cline { 2 - 6 } & \multirow{2}{*}{ Median } & Mean & SD & \multicolumn{2}{c}{ 95\% CI } & \\
Grade I & -0.29 & -0.66 & 1.45 & -1.46 & 0.14 & 0.200 \\
Grade II & -1.11 & -0.86 & 1.09 & -1.21 & -0.49 & \\
Grade III & -0.51 & -0.49 & 1.28 & -1.35 & -0.37 & \\
\hline
\end{tabular}


Indonesian Journal of Medicine (2016), 1(1): 26-33

https://doi.org/10.26911/theijmed.2016.01.01.04

\section{DISCUSSION}

In this research, the number of breast cancer patients who came from 30-49 year age group were a lot more than those who came from 50-78 year age group. It was estimated as the impact of the exposure of estrogen or progesterone hormone toward breast tissue, since the beginning of menstruation up to menopause (Hulka and Moorman, 2001). The onset during first menstruation and during menopause influences the period of hormone exposure. Proliferation of breast epithelia can be induced by estrogen (Aguas et al., 2005), and its active form that is estradiol (E2) can trigger the process of neoplastic transformation on human breast epithelia (Russo et al., 2006; Fernandez et al., 2009).

In post-menopause women, breast cancer is estimated influenced by estrogen synthesis which is related to adiposity. During menopause, ovaries no longer can produce estrogen hormone. Estrogen is obtained from androgenic precursors of adrenal glands which experience aromatization to become estrogen in adipose tissue (Kluttig and Pokrzywnak, 2009). Menopause women with obesity are having a high risk to suffer from breast cancer as the impact of high level of estrogen especially estradiol (Hulka and Moorman, 2001; Key et al., 2003). Based on the research conducted by

McTiernan et al., (2003), the increasing estrone and estradiol was found along with the increasing parameter of adiposity. In post-menopause women with obesity and breast cancer, there are is increasing parameter of adiposity which is related to the increasing level of hormones that cause tumor.

The proportion of histopathology grade of the research subjects showed the most proportions came from grade II (59.44\%), followed by grade I (23.44\%), and the smallest proportion came from grade III (17.20\%). It was similar with the study made by Yan et al., (2008), however it was different with the study made by Qian et al., (2009) where the most proportion came from grade III and the smallest was from grade I.

An analysis on miR-21 expression toward the entire research sample was conducted. Based on the comparison of average miR-21 expressions between grade, it was obtained that the highest miR-21 expression came from grade III, followed by grade I and the lowest expression was from grade II. The increasing expression of miR-21 in grade III from the research result was in accordance with the research result of Qian et al., (2009) and Lee et al., (2011).

A soaring MiR-21 expression in grade III caused an increasing regulation in a form of translation or degradation pressure by miR-21 toward tumor mRNA target tumor suppressor (among others are Network p53 and PDCD4 (Chen et al, 2012). Consequently, the function of tumor suppressor protein was extremely decreasing in term of control on cell proliferation and neoplastic transformation. The process of cell proliferation, cell differentiation, and neoplastic transformation kept on going and it was hard to control. The impact was seen from the description of grade III which were extensively varied formation of tubulus and nuclear pleomorphism, as well as excessively increasing cell mitosis, compared to grade I and II.

Otherwise, low expression of miR-21 in grade I and II caused regulation effect of miR-21 toward Mrna target tumor suppressor was also low. Consequently, cell proliferation and neoplastic transformation were still in control by tumor suppressor protein. It was in accordance with the description of grade I and II, which was the formation 
pattern of tubulus, nuclear pleomorphism, and cell mitosis relatively close to the description of normal breast tissue.

MiR-21 is known to have some target mRNA tumor suppressor, among others are PDCD4 and Network of p53 (Frankel et al., 2008; Papagiannakopoulos et al., 2008). PDCD4 is tumor suppressor protein which functions to control cell transformation process, is able to hamper c-Jun and AP-1 transactivation so that malignancy progressivity can be lowered (Yang et al., 2001; Bitomsky et al., 2004; Jansen et al., 2005). Frankel et al., (2008) found that mRNA PDCD4 could be hampered by miR-21. If miR-21 suppressed PDCD4 expression, thus would impact in the increasing of cell proliferation and transformation.

In addition to PDCD4, another tumor suppressor is p53 that functions to minimize genetic breakdown so that carcinogenetic process can be prevented. Abnormal cell proliferation can be controlled through cycle cell arrest or apoptosis, it depends on the level of DNA breakdown. In doing its functions, p53 protein needs other protein to help stabilizing and activating p53. The proteins meant are among others $H N R P K$ (Moumen et al., 2005), DAXX (Li et al., 2007), TOPORS (Lin et al., 2005). MiR-21 can suppress protein expression which is important for stabilization and activation of p53 as well as proteins which become the target of p53 transcription (Papagiannakopoulos et al., 2008). The hampered protein expression by miR-21, will impact in the increasing of cell proliferation and the decreasing of apoptosis.

Breast cancer is suffered more by productive age group, and grade II is the largest proportion of histopathology grade. By finding an escalating miR-21 in grade III (compared to grade I and II), it is even more confirming the assumption that miR-21 is an oncomiR which plays an important role in the process of malignancy development on breast cancer.

\section{REFERENCE}

Aguas F, Martins A, Gomes TP, de Sousa M, Silva DP (2005). Portuguese Menopause Society and Portuguese Gynaecology Society: Prophylaxis approach to a-symptomatic post-menopausal women: breast cancer. Maturitas 52: S23-31.

Bitomsky N, Bohm M, Klempnauer KH (2004). Transformation suppressor protein Pdcd4 interferes with JNKmediated phosphorylation of c-Jun and recruitment of the coactivator p3oo by c-Jun. Oncogene 23: 74847493.

Calin GA, Croce CM (2006). MicroRNACancer Connection: The Beginning of a New Tale. Cancer Res 66: 73907394.

Chen PS, Su JL, Hung MN (2012). Dysregulation of MicroRNAs in cancer. Review. Journal of Biomedical Science 19 (90): 1-8.

Cho WCS (2007). OncomiRs: the discovery and progress of microRNAs in cancers. Mol Cancer 6: 60-66.

Ferlay J, Shin HR, Bray F, Forman D, Mathers C, Parkin DM (2010). Estimates of Worldwide Burden of Cancer in 2008: GLOBOCAN 2008. Int. J. Cancer 127: 2893-2917.

Fernandez SV, Russo J (2009). Estrogen and Xenoestrogens in Breast Cancer. Toxicol Pathol 38: 110-122.

Frankel LB, Christoffersen NR, Jacobsen A, Lindow M, Krogh A, Lund AH (2008). Programmed cell death 4 (PDCD4) is an important functional target of the microRNA miR-21 in breast cancer cells. J Biol Chem 283 (2): 1026-1033. 
Indonesian Journal of Medicine (2016), 1(1): 26-33

https://doi.org/10.26911/theijmed.2016.01.01.04

Hulka BS, Moorman PG (2001). Breast Cancer: Hormones and other risk factors. Maturitas 38: 103-116.

Iorio MV, Ferracin M, Liu CG, Veronese A, Spizzo R, Sabbioni S, Magri E (2005). MicroRNA gene expression deregulation in human breast cancer. Cancer Res 65: 7065-7070.

Jansen AP, Camalier CE, Colburn NH (2005). Epidermal Expression of The Translation Inhibitor Programmed Cell Death 4 Suppresses Tumorigenesis.Cancer Res 65: 6034-6041.

Kementerian Kesehatan Indonesia (2013). Profil Kesehatan Indonesia Tahun 2012.http://www.depkes.go.id.

Key TJ (2003). Body Mass Index, Serum Sex Hormones, and Breast Cancer Risk in Postmenopausal Women. Endogenous Hormones and Breast Cancer Collaborative Group. J Natl Cancer Inst 95: 1218-1226.

Kluttig A, Pokrzywniak AS (2009). Established and Suspected Risk Factor in Breast Cancer Aetiology. Breast Care 4: 82-87.

Lee JA, Lee HY, Lee ES, Kim I, Bae JW (2011). Prognostic Implications of MicroRNA-21 Overexpression in Invasive Ductal Carcinomas of the Breast. J Breast Cancer 14 (4): 269-275.

Li Q, Wang X, Wu X, Rui Y, Liu W, Wang J, Wang X (2007). Daxx Cooperates with the Axin/HIPK2/p53 Complex to Induce Cell Death. Cancer Res 67: 66-74.

Lin L, Ozaki T, Takada Y, Kageyama H, Nakamura Y, Hata A, Zhang JH (2005). topors, a p53 and topoisomerase I-binding RING finger protein, is a coactivator of p53 in growth suppression induced by DNA damage. Oncogene 24: 3385-3396.

Malhotra GK, Zhao X, Band H, Band V (2010). Histological, molecular and functional subtypes of breast cancers. Cancer Biology \& Therapy 10(10): 955960.

McTiernan A, Rajan KB, Tworoger SS, Irwin M, Bernstein L, Baumgartner R (2003). Adiposity and Sex Hormones in Postmenopausal Breast Cancer Survivors, J.Clin. Oncol 21: 1961-1966.

Moumen A, Masterson P, O'Connor MJ, Jackson SP (2005). hnRNP K: An HDM2 Target and Transcriptional Coactivator of p53 in Response to DNA Damage. Cell 123: 1065-1078.

Papagiannakopoulos T, Shapiro A, Kosik KS (2008). MicroRNA-21 Targets a Network of Key Tumor-Suppressive Pathways in Glioblastoma Cells. Cancer Res 68: 8164-8172.

Qian B, Katsaros D, Lu L, Preti M, Durando A, Arisio R, Mu L (2009). High miR-21 expression in breast cancer associated with poor disease-free survival in early stage disease and high TGF- $\beta$ 1. Breast Cancer Res Treat 117: 131-140.

Rakha EA, Reis-Filho JS, Baehner F, Dabbs DJ, Decker T, Eusebi V, Fox SB (2010). Breast cancer prognostic classification in the molecular era: the role of histological grade. Breast Cancer Res 12 (207): 1-12.

Russo J, Fernandez SV, Russo PA, Fernbaugh R, Sheriff FS, Lareef HM, Garber $J$ (2006). 17-Beta-estradiol induces transformation and tumorigenesis in human breast epithelial cells. The FASEB Journal Research Communication 20: 1622-1634.

Tavassoli FA, Devilee P (2003). Pathology and Genetics of Tumours of the Breast and Female Genital Organs. World Health Organization Classification of Tumours. France: IARC Press Lyon: 18-19. 
Verderio P (2005). Quality control for histological grading in breast cancer: an italian experience. Pathological 97: 16.

Yan LX, Huang XF, Shao Q, Huang MY, Deng L, Wu QL, Zeng YX (2008). MicroRNA miR-21 overexpression in human breast cancer is associated with advanced clinical stage, lymph node metastasis and patient poor prognosis. RNA 14: 2348-2360.

Yang HS, Jansen AP, Nair R, Shibahara K, Verma AK, Cmarik JL, Colburn NH (2001). A novel transformation suppressor, Pdcd4, inhibits AP-1 transactivation but not NF-kB or ODC transactivation. Oncogene 20: 669676. 